Syntax Literate : Jurnal Ilmiah Indonesia p-ISSN: 2541-0849

e-ISSN : 2548-1398

Vol. 5, No. 1 Januari 2020

\title{
METODA PELAKSANAAN REFORMASI BIROKRASI
}

\section{Ira lusiawati}

Universitas kebangsaan

Email: Iralusia72@gmail.com

\begin{abstract}
Abstrak
Reformasi birokrasi yakni cara yang digunakan dalam melaksanakan transisi ke petunjuk yang lebih baik. Efek dari transisi yaitu terhadap struktur dan sistem yang ada dalam birokrasi yang tertera. Metode penelitian yang dipakai yakni metode penelitian kuantitatif, karena penelitian ini menggambarkan bagaimana pelaksanaan reformasi birokrasi yang terjadi, supaya pelaksanaan reformasi birokrasi dapat terlaksana dengan baik. Sehingga dapat disimpulkan metode yang digunakan adalah metode kuantitatif. Metoda pelaksanaan reformasi birokrasi dengan cara yang dilaksanakan menuju ke jalan yang lebih baik. Semenjak perekruta sampai pemberhentian ASN disusun dengan cara yang jelas serta memberikan sistem dinamisasi yang lebih cepat dan praktis, bahkan memberikan penghargaan serta punishment dengan cara proporsional dan aplikatif pun dilakukan. Hal ini dilakukan agar kerja ASN dapat memberikan pelayanan kepada publik dengan optimal, tetapi upaya reformasi birokrasi yang dilakukan belum mampu merubah pelayanan publik menjadi lebih baik karena masih banyaknya birokrat yang terjerat kasus korupsi, persengkongkolan serta penyajian kepada masyarakat kecil.
\end{abstract}

Kata kunci: Reformasi, Birokrasi, Metoda

\section{Pendahuluan}

Kemajuan suatu Negara atau Bangsa ditentukan oleh sumber daya manusianya. Petuah lama itu sangat benar adanya. Presiden pertama Republik Indonesia, Soekarno, menekankan pentingnya meningkatkan kualitas rakyat Indonesia untuk dapat bersaing dengan negara-negara lain dan membangun negaranya sendiri. Kesuksesan sebuah lembaga salah satunya bergantung pada tenaga kerja yang dimiliki. Oleh karena itu kepedulian pada bidang sumber daya manusia jangan dibiarkan dengan begitu sebab ini adalah awal mula dalam menyusun tenaga berkualitas, bisa dinyatakan dengan itu sumber daya manusia memegang fungsi yang berarti dari ketika perancangan, perumusan, sasaran dan tujuan hingga kepada rencana dalam menggapai keinginan yang diinginkan oleh negara. Mutu sumber daya aparatur menjadi peran sentral dalam peningkatan kualitas pelayanan publik. Undang-Undang Nomor 5 Tahun 2014 tentang ASN menjelaskan bahwa pengembangan peningkatan kualitas aparatur sipil negara baik PNS (pasal 69) dan PPPK (pasal 102) yaitu sebagai dorongan untuk mencapai tujuan dan sasaran pemerintahan yang baik dan pembangunan yang berkepanjangan. 
Reformasi birokrasi yaitu langkah yang dilakukan supaya bisa melakukan perubahan ke arah yang lebih baik. Dampaknya berpengaruh pada struktur dan sistem pada reformasi demokrasi. Sistem reformasi ini saling berikatan dengan yang lainnya. Akan tetapi struktur berikatan dengan susunan yang sudah ditata. Dalam melakukan perubahan ini meliputi SDM, sarana, pemerintahan ataupun wilayah yang akan dilakukan perubahannya. Oleh karenanya reformasi birokrasi tersebut mengikat pada sistem dan struktur yang ada dalam reformasi birokrasi, untuk melakukan perubahan dengan cara komprehensif dan dinamis yang serasi untuk keperluan aturan ke arah yang lebih baik.

Undang-Undang Nomor 5 Tahun 2014 mengenai Aparatur Sipil Negara (ASN) yang menjadi benteng dalam penaikan kualitas SDM supaya menjadi takaran di pemerintah. Sejak penyeleksian samapai kepada pemberhentian ASN ditata dengan jelas dan memberikan sistem dinamisasi yang cepat dan efisien, Kebijakan yang telah dibuat itu memberi dampak yang besar kepada ke profesionalitas akan kemampuan para kinerja ASN. Semenjak pemilihan hingga ke pemberhentian ASN yang telah diatur dengan jelas dan memberikan sistem dinamisasi secara cepat adan efisien. Pemerintah memberikan penghargaan dan punishmen dengan cara proporsional dan aplikatif. Dalam memperkuatkan ASN mengenai ASN dengan Undang-Undang Nomor 5 Tahun 2014 yang didukung oleh Undang-Undang Nomor 25 Tahun 2009 mengenai pelayanan punlik yang bisa dijadikan sebagai penopang utama untuk menaikan bobot kerja para pekerja. Dapat di nilai pelaksanaan birokrasi di Indonesia masih terbilang rendah, hal ini diakibatkan karena masih banyak para pekerja pemerintah yang terjerat kasus korupsi, dan masih banyak kecurangan.

Pemerintah sudah banyak dalam melaksanakan usaha dalam memajuakan pelayanan dengan cara melaksanakan penilaian terhadapa kemampuan para pekerja dan memeberikan apresiasi citra pelayanan prima bagi badan pemerintahan yang mempunyai performa. Semenjak tahun 1959 pemerintahan sudah mentapkan aturan untuk lebih menekankan korupsi dengan cara memeberikan penghargaan serta punishment. Pemberiaan penghargaan kepada para pekerja mempunyai tanggapan masing-masing ada yang mengatakan bahwa hal tersebut kurang mempunyai faedah. Signifikan. Dalam meningkatkan kemakmuran. Akan tetapi punishment yaitu denda yang dikeluarkan untuk para pekerja yang tidak bisa dikendalikan terhadap otonomi daerah. Dapat terjadinya hal ini akibat dari separuh wilayah mengalami surplus pekerja yang mempunyai tanggung jawab yang semakin berkurang. Banyak pila pekerja yang tidak produktivitas dengan kemampuan dan dilihat dari penilaian kedipsinan serta tidak optimal disiplin administratif dan kurangnya kerjasama dengan produktivitas dan masih banyak tindakan yang tidak sesuai aturan yang dibuat.

Kebijakan publik menjadi penting bagi pegawai dalam menjalankan tugas dan fungsinya. Kebijakan publik tidak hanya sebuah aturan dan susunan aturan yang berupa tekstual, namun mesti dipahami bahwa setiap kebijakan merupakan substansi pekerjaan yang wajib diselesaikan sesuai dengan waktu yang sudah direncanakan. Kebijakan publik mempunyai 3 unsur yang ada didalamnya; yaitu: formulasi kebijakan, 
implementasi, serta evaluasi kebijakan. Dari ketiga unsur adalah syarat wajib yang harus ada supaya dapat terwujudnya tujuan dari organisasi. Unsur yang sudah dibuat mesti berjalan dengan sinergis dan berkesinambungan. Yang merupakan syarat utama dalam melaksanakan reformasi birokrasi dan perolehan good governance. Dari hal tersebut, kebijakan terhadap penilaian kemampuan pelayanan publik menjadi penting dilaksanakan dengan secara professional yang bersangkutan pada mekanisme penghargaan dan punishment.

Di dalam pelaksanaan reformasi birokrasi terdapat delapan area penataan. Delapan area tersebut ialah Organisasi, Tatalaksana, Peraturan Perundang-undangan, SDM Aparatur, Pengawasan, Akuntabilitas, Pelayanan Publik, Mindset dan Cultur set. Kedelapan area penataan tersebut merupakan sasaran dari agenda reformasi birokrasi yang dicanangkan pemerintah dan salah satu area penataan reformasi birokrasi yaitu penataan Sumber Daya Manusia, dimana diharapkan mampu tercipta SDM Aparatur yang berkredibilitas, netral, terlatih, profesional, berkinerja tinggi, bertanggung jawab dan sejahtera. Sumber Daya Manusia itu sendiri dapat tercipta dengan baik apabila didukung oleh budaya kerja yang baik pula, dimana setiap individu mampu memberikan dampak membangun atau positif pada organisasi dimana ia berada. Hal yang paling menarik dalam pemerintahan saat ini ialah hilangnya atau berkurangnya nilai-nilai dalam bekerja seperti budaya malu pada diri Aparatur Sipil Negara, hal ini bisa kita lihat dari maraknya kasus korupsi, kasus pelanggaran kode etik, kasus asusila, kasus narkoba, kasus suap dan berbagai kasus lainnya yang menjerat para Aparatur Sipil Negara. Dalam situasi reformasi birokrasi, tujuan fundamental dari pengembangan budaya kerja berusaha memperbaiki budaya kerja yang sudah ada menjadi budaya yang berkembang sifat dan tindakan kerja yang mengarah terhadap hasil (outcome) dan produktivitas kerja serta kinerja yang baik. Pada metoda pelaksaan reformasi birokrasi budaya kerja dipahami sebagai culture set, atau selaku cara pandang seseorang dalam memberi makna kepada "kerja" sehingga pencapaian peningkatan kualitas bersumber dari individu yang terkait dalam organisasi itu sendiri sebagai cerminan dari sikap yang berlandaskan terhadap nilai-nilai serta norma-norma individu masing-masing. Membangun kultur baru, dengan upaya-upaya merubah kultur saat ini yang begitu buruk, dimana konotasi negatif yang melekat seperti mekanisme dan prosedur yang berbelit-belit, dan penyalahgunaan status atau wewenang perlu diubah. Hal ini dengan cara dilaksanakan perbaikan kultur dan etika birokrasi dengan rancangan transparansi, melayani secara terbuka dengan gamblang kode etiknya, sehingga tingkat kepercayaan serta kepuasan masyarakat tercapai. Untuk menjaga dan meningkatkan kualitas tersebut dibutuhkan modal yang tidak sedikit, seiring dengan kebutuhan SDM yang berkualitas, maka ada kesesuianan gaji atau penghasilan yang diberikan negara kepada aparatur sipil negara, diharapkan dengan meningkatnya penghasilan para ASN ini bisa melayani masyarakat dengan baik dan perilaku-perilaku negatif yang selama ini tercermin di perilaku ANS dapat diminimalkan.

Disahkannya Undang-undang No. 22 Tahun 2000 mengenai Pemerintahan Daerah dan Undang-undang No. 25 Tahun 2000 mengenai Perimbangan Keuangan 
Pusat dan Daerah memberikan kesempatan pada pemerintah daerah untuk berimprovisasi dalam Perencanaan dan pelaksanaan Pembangunan. Adanya kewenangan daerah dalam mengatur daerahnya sendiri, termasuk mengatur kewenangan kepegawaian, memberi peluang kepada pemerintah daerah untuk kreatif dan inovatif dalam memberdayakan pegawainya. Terdapat beberapa faktor yang memberikan dorongan pegawai untuk bekerja lebih baik misalnya imbalan yang proposional, kenaikan pangkat, suasana kerja yang kondusif, hubungan kerja antara atasan dan bawahan, serta cara sosialisasi dan mengkomunikasikan penyebaran informasi mengenai program pembinaan pegawai.

Kota Bandung adalah salah satu kota yang sudah melaksanakan kenaikan gaji dengan menggunakan sistem tersendiri yang disebut dengan sistem e-RK, seperti dilansir Bandung, Kompas.com, gaji ANS kota Bandung paling kecil itu Rp.12 juta, penghasilan kepala dinas Rp 30 juta-Rp 40 juta. Besarnya penghasilan ANS Adalah efek karena adanya aplikasi bernama e-RK (Remunerasi Kinerja Elektronik).

E-RK adalah aplikasi yang digunakan untuk menghitung jam kerja para pegawai dengan normal waktu 6000 menit per bulan. Angka perolehan itu menumpu faktor lain, salah satunya absensi, dengan sistem ini diharapkan kinerja ANS dapat dinilai dengan asas keadilan, sehingga dapat meningkatkan SDM yang menjadi lebih berkualitas dan penghasilan pegawai bergantung pada rajin tidaknya pegawai. Reformasi penghasilan ini dapat merubah budaya kerja, dulu siapa yang namanya tercantum dalam kegiatan, amplopnya tebal. Maka berlomba-lombalah ANS agar namanya tercantum. Dulu untuk fotokopi saja ada honornya, dimana honornya lebih besar daripada fotocopinya. Perubahan dengan akses keadilan kinerja dinamis siapa-siapa yang bisa memberikan kinerja 6000 menit, maka akan mendapatkan tunjangannya. Perubahan ini diharapkan dapat menghalau penilaian negatif tentang kinerja aparatur sipil negara, dan SDM pun semakin berkualitas.

Rumusan pertanyaan penelitian dalam makalah ini adalah "Bagaimana reformasi birokrasi kenaikan gaji atau upah sumber daya manusia dapat mengotimalkan kinerja yang berkualitas".

Budaya merupakan nilai-nilai yang dimiliki manusia, bahkan mempengaruhi sikap dan perilaku manusia. Dengan kata lain, semua manusia merupakan aktor kebudayaan karena manusia bertindak dalam lingkup kebudayaan. Beberapa pendapat para ahli tentang definisi budaya antara lain: Menurut Alisyahban dalam (Supartono, 2004) budaya merupakan "manifestasi dari cara berfikir, hingga menurut pola kebudayaan itu sangat luas akibat semua tingkah dan tindakan, meliputi di dalamnya perasaan karena perasaan juga ialah maksud dari pikiran”. Pendapat lain dikemukakan oleh (Hofstede, 2007) yang mengemukakan bahwa budaya bisa didefinisikan sebagai "berbagai interaksi dari ciri-ciri kebiasaan yang mempengaruhi kelompok kelompok orang dalam lingkungannya". Selanjutnya Menurut G Graham dalam (Siswadi \& Mahatma, 2012) budaya organisasi adalah "norma, keyakinan, sikap dan filosofi organisasi. Kebudayaan adalah suatu sistem nilai, keyakinan dan norma-norma yang unik yang dimiliki secara bersama oleh anggota suatu organisasi. Kebudayaan juga 
menjadi suatu penyebab penting bagi keefektifan organisasi itu sendiri”. Menurut peneliti dari berbagai pendapat tersebut pada intinya menjelaskan bahwa budaya organisasi adalah sistem keyakinan dan nilai-nilai organisasi yang dijiwai oleh seluruh anggotanya untuk melaksanakan pekerjaan sebagai langkah yang tepat untuk memahami, memikirkan dan merasakan kepada masalah yang ada terkait,sehingga akan menjadi sebuah nilai atau aturan dalam organisasi tersebut. Sedangkan budaya itu sendiri ialah satu unit interpretasi, ingatan, serta makna yang ada di dalam manusia dan bukan sekadar dalam kata-kata. Ia meliputi kepercayaan, nilai-nilai, dan norma. Budaya mempengaruhi perilaku manusia sebab setiap orang akan memperlihatkan kebudayaannya saat ia berperilaku.

Pengertian Budaya Kerja Menurut (Taliziduhu, 2003), budaya kerja dapat dibagi menjadi dua unsur, yaitu: 1) Sikap terhadap pekerjaan, yakni kesukaan akan kerja dibandingkan dengan kegiatan lain, seperti bersantai, atau semata-mata memperoleh kepuasan dari kesibukan pekerjaannya sendiri, atau merasa terpaksa melakukan sesuatu hanya untuk kelangsungan hidupnya. 2) Perilaku pada waktu bekerja, seperti rajin, berdedikasi, bertanggung jawab, berhati-hati, teliti, cermat, kemauan yang kuat untuk mempelajari tugas dan kewajibannya, suka membantu sesama pegawai, atau sebaliknya. Berdasarkan dua unsur menurut Taliziduhu Ndraha tersebut menurut peneliti pada hakekatnya budaya kerja merupakan bentuk atau cara individu maupun kelompok dalam mengaktualisasikan diri. Dimana bekerja merupakan bentuk nyata dari nilai, kepercayaan dan pemahaman yang dianut dan dapat menjadi motivasi untuk menghasilkan kinerja atau karya yang bermutu. Hal tersebut dapat terlihat dari bagaimana sikap kita terhadap pekerjaan maupun perilaku kita pada waktu bekerja. Adapun indikator-indikator budaya kerja menurut (Taliziduhu, 2003) dapat dikategorikan tiga Yaitu: 1) Kebiasaan. Kebiasaan-kebiasaan biasanya bisa dilihat dengan langkah pembuatan tindakan berorganisasi pegawai, yakni tindakan menurut kesadaran akan hak dan kewajiban, kebebasan atau wewenang dan kewajiban baik perorangan ataupun kelompok di dalam ruang lingkup lingkungan pekerjaan. mengenai kata lain yang bisa disangka lebih kuat ketimbang sikap, yaitu pendirian (position), seandainnya sikap dapat berubah pendiriannya diharapkan tidak berdasarkan keteguhan atau kekuatannya.

Maka bisa dijelaskan bahwa tindakan ialah cermin sistem tingkah laku maupun tindakan sering dilaksanakan baik didalam kondisi sadar maupun dalam kondisi tidak sadar, kebiasaan lazimnya rumit diperbaiki dengan cara sigap disebabkan sifat yang dibawa semenjak lahir, akan tetapi bisa ditindak lanjuti dengan ketesediaan aturanaturan yang bijak baik dari organisasi maupun perusahaan. Berkaitan mengenai indikator kebiasaan, hal ini dapat dijabarkan kedalam dua sub indikator yaitu: a. Bagaimana kebiasaan dilihat dari pelaksanaan beban penting dan peranan yang dijalankan atau bagaimana seorang pegawai bertanggung jawab terhadap pekerjaannya. Menurut jurnal Muhammad Asyakir Zaili Rusli Fisip Universitas Riau mengungkapkan bahwa: "Tugas pokok dan fungsi (Tupoksi) merupakan kesatuan pekerjaan atau kegiatan yang dilaksanakan oleh para pegawai yang memiliki aspek khusus serta saling 
berkaitan satu sama lain menurut sifat atau pelaksanaannya untuk mencapai tujuan tertentu dalam sebuah organisasi". Didalam organisasi pemerintahan, beban penting serta peranan ialah bagian yang tidak bisa dipisahkan dari kehadiran organisasi tersebut. Ketetapan beban penting serta peranan dari sebuah unit organisasi menjadi dasar hukum unit organisasi tersebut dalam melakukan kegiatan sekaligus selaku peringatan dalam melakukan tugas dan pengaturan terhadap tataran aplikasi dilapangan. b. Kebiasaan dapat dilihat dari pelaksanaan disiplin pegawai pada suatu organisasi, yang dalam penelitian ini ialah melihat bagaimana disiplin pegawai tersebut membangun kebiasaan dalam diri tiap individunya. Menurut Malayu SP. Hasibuan dalam bukunya Dasar Kunci keberhasilan Manajemen Sumber Daya Manusia (2001:193) Disiplin adalah "kesadaran dan kesediaan orang-orang mentaati semua peraturan perusahaan atau organisasi dan norma-norma sosial yang berlaku". 2) Kebijakan dalam memberikan ketentraman dan kenyaman dalam melakukan beban pekerjaan pegawai, oleh karena itu dibutuhkan adanya aturan sebab kebijakan adalah bentuk ketegasan serta bagian ynag paling penting dalam menggapai pegawai disiplin serta mentaati aturan dalam bentuk sebuah aturan yang telah berlaku. Atau organisasi. Sehingga diharapkan pegawai memiliki tingkat kesadaran yang tinggi sesuai dengan konsekuensi terhadap peraturan yang berlaku baik dalam organisasi perusahaan maupun di lembaga pemerintahan. Pelaksanaan peraturan dapat dilihat dari bagaimana aturan atau kebijakan yang diterapkan dan bagaimana sanksi diberlakukan. Hal ini untuk melihat sejauhmana peraturan tersebut mempunyai peranan dalam mewujudkan budaya kerja yang baik dan sdm yang baik pula.

Manajemen Sumber Daya Manusia Menurut (Saefullah, 2010) manajemen SDM dikelompokan sebagai langkah menyaring serta mengembangkan SDM yang memiliki peluang dalam menggapai tujuan perusahaan. Menurut Sule dan (Saefullah, 2010) manajemen SDM bisa di kelompokan selaku cara dalam menilai serta memotivasi SDM yang selaras dengan tolak ukur perusahaan yang bisa memberikan keuntungan kepada perusahaan tersebut. Menurut (Hamid, 2014) Tugas utama manajemen SDM yakni menggarap manusia secara full dengan cara kepemimpinan (leadersship process) supaya bisa diperoleh kinerja SDM dalam menjalankan peranan dan tugasnya dalam organisasi. Menurut (Bangun, 2012) Manajer SDM ialah seseorang yang melakukan tugas SDM dengan mempererat kerja sama dengan para anggota lain guna menyelesaikan masalah yang muncul dalam perusahaan. Menurut (Nawawi et al., 2008) organisasi/perusahaan harus meninggalkan konsep mencari dan memberdayakan SDM berkeahlian yang bersedia diupah dengan gaji yang murah, dan membiarkannya berhenti dengan asumsi Masih banyak pencari kerja untuk menggantinya. Menurut (Bangun, 2012) manajemen SDM akan mengirimkan tenaga kerja ke berbagai bidang di organisasi-organisasi lain sesuai kebutuhannya. Ini menunjukan bahwa manajemen sumber daya manusia mempunyai keterkaitan dengan manajemen bidang lain dalam organisasi untuk mencapai hasil kerja yang efektif. Fungsi-fungsi manajemen sumber daya manusia ada lima, antara lain: 1. Pengadaan Sumber Daya Merupakan sebuah kegiatan untuk mendapatkan atau merekrut karyawan menurut seberapa yang 
dibutuhkan guna mencapai tujuan organisasi. Pengadaan tenaga kerja mencakup hal-hal berikut, yaitu: a. Analisis pekerjaan. b. Perencanaan SDM c. Rekrutmen SDM d. Seleksi dan penempatan SDM 2. Pengembangan sumber daya Pengembangan mencakup hal-hal berikut ini, yaitu: a. Pengembangan SDM b. Pengembangan karir c. Pengembangan organisasi d. Manajemen dan penilaian kinerja 3. Kompensasi. Kompensasi adalah hasil yang menjadi hak karyawan atas pekerjaaan yang sudah disumbangkan selama bekerja disuatu perusahaan. Kompensasi mencakup hal-hal berikut, yaitu: a. Kompensasi finansial b. Kompensasi bukan finansial. 4. Pengintegrasian. Pengintegrasian diartikan menyamakan harapan karyawan dengan keperluan organisasi. Pengintegrasian meliputi hal-hal dibawah ini, yakni: a. Motivasi kerja b. Kepuasan dalam bekerja c. Kepemimpinan 5. Pemeliharaan SDM Pemeliharaan SDM artinya memelihara tenaga kerja untuk setia dengan organisasi dan tetap menjadi anggota organisasi tersebut. Pemeliharaan SDM mencakup beberapa hal berikut ini, yaitu: a. Komunikasi b. K3 (Keselamatan dan kesehatan kerja). Kesimpulan yang bisa di peroleh dari pendapat para ahli diatas yakni manajemen SDM ialah suatu kegiatan dalam mengelola individu atau kelompok secara baik melalui proses kepemimpinan (leadership process) untuk pencapaian tujuan perusahaan. Fungsi manajemen SDM itu sendiri yaitu pengadaan sumber daya, pengembangan sumber daya, kompensasi, pengintregasian dan pemeliharaan SDM.

Pengertian Gaji Menurut (Ruky, 2006) gaji bisa dikelompokkan sebagai hasil atas kerja keras dan pengabdian SDM yang diberikan oleh perusahaan dalam periode tertentu. Selain itu tenaga kerja yang menerima gaji termasuk dalam kategori fixed costs. Menurut (Bangun, 2012) untuk mendapatkan penghasilan besar, para pekerja selalu menaikkan keterampilannya untuk mewujudkan kinerja yang lebih baik. Menurut (Tisnawati Sule \& Saefullah, 2010) program yang perlu dilakukan oleh perusahaan berkaitan dengan sistim pengupahan. Menurut (Hasan et al., 2009) gaji dan upah dapat disusun menurut prestasi kerja karyawan, lama kerja karyawan, senioritas, dan kebutuhan hidup tenaga kerja. Menurut (Sarosa, 2009) fungsi penggajian harus memenuhi aturan dan perundang-undangan ketenagakerjaan yang berlaku, misalnya upah minimum, perpajakan, lembur dan kebutuhan manajerial. Menurut (A. Sugiyono, 2010) seberapa besar upah dan gaji yang diperoleh karyawan diseleraskan dengan kualitas dan pengabdiannya kepada perusahaan, diakibatkan karena adanya perolehan bahwa besarnya gaji yang didapat karyawan menentukan kualitas karyawan. Menurut (Bangun, 2012) sebagian perusahaan memberikan gaji kepada tenaga penjualan sebagai bayaran jasa yang mereka berikan dalam kegiatan penjualan. Menurut (Siagian, 2015) pola bayaran dalam mengelola SDM tidak harus dalam bentuk uang atau materi saja.

Pemberian imbalan bisa diberikan dengan bentuk tunjangan, kenaikan pangkat, sarana prasarana yang dibutuhkan oleh karyawan, dan hak cuti dan liburan yang sama dengan aturan kerja sehingga karyawan tetap mendapatkan upah atau gaji yaang penuh. Menurut (Siagian, 2015) yang dimaksud prinsip keadilan ialah hasil yang diperoleh tenaga kerja berdasarkan tiga hal, yaitu: 1. Keadilan internal 2. Keadilan eksternal 3. Imbalan yang didapat pekerja dalam taraf wajar. Menurut (Siagian, 2015) dalam 
mengembangkan sistim imbalan, hal yang dapat dilakukan antara lain ada empat, yaitu: 1. Melakukan analisa pekerjaan 2. Melakukan penilaian pekerjaan dikaitkan dengan keadilan internal 3. Melakukan survai sistim imbalan guna memperoleh bahan yang berkaitan dengan keadilan eksternal 4. Menentukan "harga" setiap pekerjaan dihubungkan dengan "harga" pekerjaan sejenis ditempat lain. Menurut (Siagian, 2015) faktor yang mempengaruhi sistim imbalan adalah sebagai berikut: 1. Tingkat upah dan gaji yang berlaku 2. Tuntutan serikat pekerja 3. Produktivitas 4. Kebijaksaan organisasi mengenai upah atau gaji 5. Peraturan perundang-undangan dari pemerintah Menurut (Bangun, 2012) banyak dari perusahaan memakai pembayaran gaji ditambah dengan komisi sebagai pola kompensasi bagi tenaga penjual. Pola pelunasan yang paling terkenal dilaksanakan dengan pertimbangan 70 persen gaji serta 30 persen komisi. Kesimpulan dari penjelasan tersebut ialah gaji menjabarkan pelunasan atas kerja keras pekerja yang mempunyai waktu ke waktu khusus dan mesti mencukupi kebijakan dan perundang-undangan ketenagakerjaan yang berjalan dan semua kenaikan gaji dan upah otomatis akan meninggikan biaya pasti perusahaan. Gaji bisa ditata menurut prestasi kerja karyawan, lama kerja karyawan, senioritas, serta kebutuhan hidup pekerja.

Fungsi dari gaji tersebut sendiri mesti mencukupi kebijakan perundang-undangan ketenagakerjaan yang telah ditetapkan, seperti upah minimum, perpajakan, lembur serta kebutuhan manajerial. Kinerja Karyawan Menurut (Bangun, 2012) kinerja ialah hasil dari perolehan kerja seseorang menurut standart dan persyaratan kerja yang telah di resmikan di perusahaan. Menurut (Bangun, 2012) kemampuan seorang karyawan bisa dilihat menurut bobot pekerjaan yang bisa dituntaskan serta mutu kerja melebihi standart pekerjaan, hingga karyawan itu bisa dilihat dengan kemampuan yang baik.Suatu pekerjaan bisa dinilai dengan berikut, yakni: 1. Bobot pekerjaan yang bisa dikerjakan. 2. Mutu pekerjaan karyawan 3. Pasnya waktu dalam bekerja 4. Kehadiran 5. Kinerja kerja sama dengan karyawan lain. Menurut (Siagian, 2015) evaluasi pekerjaan ialah cara dalam memberikan nilai sama dengan hasil kemampuan karyawan yang berhubungan. Menurut (Bangun, 2012) cara pemberian nilai terhadap kemampuan karyawan ini bermaksud dalam mempertimbangkan bobot kompensasi yang akan didapat para pekerja.

Menurut (Manullang, 2013) evaluasi pegawai bisa dipakai dalam hal-hal sebagai berikut: 1. Sebagai dasar pembayaran imbalan serta bonus 2. Sebagai alat dalam mengawasi dan melaksanakan tugas suatu pekerjaaan 3. Sebagai alat yang dipakai dalam latihan 4. Sebagai alat pemberian perangsangan oleh setiap karyawan. Menurut (Siagian, 2015) maksud evaluasi pekerjaan ialah bisa memastikan pekerjaan mana yang akan dilunasi dengan bayaran tinggi dan pekerjaan mana yang akan memperoleh bayaran rendah. Menurut (Manullang, 2013) ada 3 kemungkinan yang mengadakan evaluasi, yaitu: 1. Pemberian nilai kepada pegawai yang dilaksanakan dari atasan serta diperbaiki oleh kepala bagian perusahaan 2. Pemberian nilai terhadap pegawai oleh atasan serta dibantu oleh pembantu atasan 3. Pemberian nilai terhadap pegawai oleh atasan serta dinilai lagi oleh orang lain selama hasil penilaian kurang memuaskan. Menurut (Manullang, 2013) ada lima macam metode pemberian nilai, yaitu: 1. Ranking 
Method 2. Membandingkan Karyawan dengan Karyawan 3. Grading Method 4.Check List Method 5. Graphic Raiting Method. Kesimpulan yang di dapat dari pendapat para ahli diatas kinerja karyawan merupakan hasil kerja pekerja yang telah dilakukan untuk mencapai tujuan perusahaan/organisasi berdasarkan persyaratan pekerjaan yang sudah ditentukan. Kinerja karyawan dapat diukur melalui jumlah pekerjaan yang dapat dilakukan, kualitas pekerjaan, ketepatan waktu dalam bekerja, kehadiran dan kemampuan kerja sama dengan karyawan lain. Penilaian pekerjaan dapat dilihat dari hasil kerja yang lebih tinggi dari standar kerja dan penilaian tersebut dapat digunakan untuk pembayaran upah, gaji dan bonus, alat untuk pengawasan kerja, alat untuk latihan dan alat pemberian rangsangan. Penetapan Gaji Dengan Kinerja Karyawan Gaji adalah hak yang harus diberikan perusahaan kepada tenaga kerjanya atas pekerjaan dan tanggung jawab yang diberikan selama kurun waktu tertentu. Sedangkan kinerja karyawan merupakan hasil kerja karyawan atas pekerjaan dan tanggung jawab yang telah diberikan oleh karyawan kepada perusahaan.

Gaji atau upah dan masa kerja merupakan dua hal yang dapat menyebabkan penurunan kualitas sumber daya manusia, di mana perbedaan imbalan seringkali menjadi unsur berpengaruh yang mempengaruhi kemampuan dari waktu ke waktu.

\section{Metode Penelitian}

Penelitian ini menggunakan jenis penelitian deskriptif kuantitatif, yaitu suatu metode yang digunakan untuk menggambarkan yang sebenarnya berdasarkan apa yang nampak, biasanya dilakukan dianalisis yang dapat memberikan gamabaran yang lebih jelas mengenai objek yang diteliti (P. D. Sugiyono, 2010).

\section{Hasil dan Pembahasan}

Setiap organisasi menyadari bahwa keberhasilan atau kesuksesan yang akan dicapai bergantung kepada sumber daya manusianya yang berkualitas. Untuk menjadikan sumber daya manusia yang berkualitas dalam organisasi pemerintahan seringkali dilakukan berbagai metoda pelaksanaan reformasi birokrasi dengan upaya mendasar untuk melakukan perubahan ke arah yang lebih baik. Sejak perekrutan hingga pemberhentian ASN diatur secara gamblang dan memberikan pola dinamisasi yang lebih efektif dan efesien, bahkan memberikan reward dan punishment secara proporsional dan aplikatif pun dilakukan. Hal ini dilakukan agar kerja ASN dapat memberikan pelayanan kepada publik dengan optimal, tetapi upaya reformasi birokrasi yang dilakukan belum mampu merubah pelayanan publik menjadi lebih baik karena masih banyaknya birokrat yang tersandung kasus korupsi, kolusi dan pelayanan kepada publik yang masih rendah. Banyaknya ASN yang bekerja hanya mengejar besarnya imbalan atau insentif yang besar dimana mereka akan melakukan pekerjaan yang memungkinkan amplopnya tebal, ini membuat di beberapa pelayanan rendah tetapi di tempat yang lain begitu banyak orang melayani dengan baik. Dalam konteks reformasi birokrasi, tujuan fundamental sumber daya manusia yang dirubah dari pengembangan 
budaya kerja berupaya mengubah budaya kerja saat ini menjadi budaya perilaku kerja yang berorientasi pada hasil dan produktivitas kerja serta kinerja yang baik.

Pada metoda pelaksanaan reformasi birokrasi budaya kerja dipahami sebagai culture set, atau sebagai cara pandang seseorang dalam memberi makna terhadap"kerja" sehingga pencapaian peningkatan kualitas bersumber dari individu yang terkait dalam organisasi itu sendiri. Membangun suatu kultur baru pada organisasi pemerintahan bukan suatu yang mudah, walaupun dengan berbagai langkah dan upaya yang pernah dilakukan tetap tidak bisa mengubah hal-hal negatif yang sudah begitu melekat seperti mekanisme dan prosedur yang berbeli-belit. Untuk menjaga dan meningkatkan kualitas pekerja di dalam mencapai tujuan organisasi berdasarkan kinerja karyawan melalui jumlah pekerjaan yang telah dilakukan, kualitas pekerjaan, ketepatan waktu dalam bekerja, kehadiran dan kemampuan kerjasama dengan karyawan lain sehingga kualitas sumber daya aparatur akan menjadi peran sentral dalam peningkatan pelayanan terhadap publik. Hal ini berkenaan dengan undang-undang nomor 5 tahun 2014 tentang ASN menjelaskan pengembangan peningkatan kualitas aparatur sipil negara baik PNS (pasal 69) dan PPPK (pasal 102) yaitu sebagai dorongan untuk mencapai tujuan dan sasaran pemerintahan yang baik dan pembangunan yang berkelanjutan.

Upaya peningkatan gaji atau upah menjadikan bagian dari suatu perubahan di dalam reformasi birokrasi untuk pengoptimalisasi sumber daya manusia dalam pelayanan publik. Gaji atau upah dan masa kerja merupakan dua hal yang dapat meningkatkan sekaligus juga menyebabkan penurunan kualitas sumber daya manusia, dimana perbedaan upah dan ketidakadilan seringkali menjadi faktor yang dominan yang mempengaruhi kinerja dari waktu ke waktu. Disyahkannya Undang-undang No 22 tahun 2000 tentang Pemerintahan Daerah dan Undang-undang No 25 tahun 2000 tentang perimbangan keuangan pusat dan daerah memberikan kesempatan pada pemerintah daerah untuk berimprovisasi dalam pelaksanaan dan perencanaan pembangunan. Kota Bandung adalah salah satu kota yang sudah melaksanakan kenaikan gaji dengan menggunakan sistem tersendiri yang disebut dengan sistem e-RK, seperti dilansir Bandung, Kompas.com, gaji ANS kota Bandung paling kecil itu Rp.12 juta, penghasilan kepala dinas Rp 30 juta-Rp 40 juta. Besarnya penghasilan ANS kota Bandung merupakan dampak kehadiran aplikasi bernama e-RK (Remunerasi Kinerja Elektronik). E-RK merupakan aplikasi untuk menghitung jam kerja kinerja pegawai dengan standar waktu 6000 menit per bulan. Angka penghasilan itu juga ditunjang faktor lain, salah satunya absensi, dengan sistem ini diharapkan kinerja ANS dapat dinilai dengan asas keadilan, sehingga dapat meningkatkan sumber daya manusia yang menjadi lebih berkualitas dan penghasilan pegawai bergantung pada rajin tidaknya pegawai. Diharapkan dengan meningkatnya penghasilan para ASN ini bisa melayani masyarakat dengan baik dan perilaku-perilaku negatif yang melekat yang selama ini tercermin diperilaku ASN dapat diminimalkan. 


\section{Kesimpulan}

Kemajuan suatu negara dapat dilihat dari oleh sumber daya manusianya. Jika kualitas sumber daya manusianya baik, maka dapat menjadi modal besar untuk bersaing dengan negara lain. Untuk mencapai kulaitas sumber daya yang baik, maka negara harus melakukan perubahan. Perubahan yang dapat dilakukan salah satunya dengan melaksanakan reformasi birokrasi. Perubahan reformasi birokrasi mencakup sumber daya manusia, sarana prasarana, organisasi maupun lingkungannya. Reformasi birokrasi mengikat terhadap sistem dan struktur yang ada dalam birokrasi untuk melakukan berbagai perubahan secara komprehensif dan dinamis sesuai dengan kebutuhan menuju tatanan yang lebih baik. Dapat kita lihat pelayanan publik pada birokrasi Indonesia masih terbilang rendah, karena banyaknya birokat yang tersandung kasus korupsi, kolusi Pemerintah sudah cukup banyak melakukan usaha-usaha perbaikan pelayanan melalui penilaian kinerja dan penghargaan citra pelayanan prima bagi lembaga pemerintah yang berprestasi. 


\section{BIBLIOGRAFI}

Bangun, A. (2012). Ensiklopedia Tanaman Obat Indonesia. Bandung: Indonesia Publishing House.

Hamid, S. (2014). Manajemen Sumber Daya Manusia Lanjutan. Yogyakarta: Deepublish, 95-96.

Hasan, A. M., Samsudin, K., Ramli, A. R., Azmir, R. S., \& Ismaeel, S. A. (2009). A review of navigation systems (integration and algorithms). Australian Journal of Basic and Applied Sciences, 3(2), 943-959.

Hofstede, G. (2007). Asian management in the 21st century. Asia Pacific Journal of Management, 24(4), 411-420.

Manullang, B. (2013). Grand Desain Pendidikan Karakter Generasi Emas 2045. Jurnal Pendidikan Karakter, 1.

Nawawi, S. W., Ahmad, M. N., \& Osman, J. H. S. (2008). Real-time control of a twowheeled inverted pendulum mobile robot. World Academy of Science, Engineering and Technology, 39, 214-220.

Ruky, A. S. (2006). Sistem Manajemen Kinerja (Performance Management System). Jakarta: Gramedia Pustaka Utama.

Saefullah, D. (2010). Pemikiran Kontemporer Administrasi Publik. Bandung: Lp3An Fisip Unpad.

Sarosa, S. (2009). Sistem Informasi Akuntansi. Gramedia Widiasarana Indonesia.

Siagian, R. E. F. (2015). Pengaruh minat dan kebiasaan belajar siswa terrhadap prestasi belajar matematika. Formatif: Jurnal Ilmiah Pendidikan MIPA, 2(2).

Siswadi, E., \& Mahatma, M. (2012). Birokrasi masa depan: menuju tata kelola pemerintahan yang efektif dan prima. Mutiara Press.

Sugiyono, A. (2010). Peran PLTN dalam Mendukung Komitmen Pemerintah untuk Mengurangi Emisi CO2. Prosiding Seminar Pengembangan Energi Nuklir Tahun, 199-206.

Sugiyono, P. D. (2010). Metode penelitian pendidikan. Pendekatan Kuantitatif.

Supartono, W. (2004). Ilmu budaya dasar. Jakarta: Ghalia Indonesia.

Taliziduhu, N. (2003). Budaya organisasi. Jakarta: Rineka Cipta.

Tisnawati Sule, E., \& Saefullah, K. (2010). Pengantar Manejemen Edisi Pertama. Jakarta: Kencana. 